\title{
Developmental Changes in the Fatty (fafa) Rat: Evidence for Defective Thermogenesis Preceding the Hyperlipogenesis and Hyperinsulinaemia
}

\author{
V. Godbole, D. A. York, and D. P. Bloxham \\ Departments of Biochemistry and Nutrition, School of Biochemical and Physiological Sciences, Southampton University, \\ Southampton, England
}

\begin{abstract}
Summary. Preobese "fatty" rats have been identified by their lower rectal temperature. Of 51 pups born from matings of heterozygote (Fafa) parents, 16 had low rectal temperatures from day 16 onward (34.6 \pm $0.2^{\circ} \mathrm{C}$ v $35.4 \pm 0.3^{\circ} \mathrm{C}$ ) and all subsequently became obese. No animal with the higher 'normal' rectal temperature developed obesity. Hepatic fatty acid synthesis (preobese $0.6 \pm 0.1$; lean $0.6 \pm 0.1 \mu \mathrm{mol} /$ $\mathrm{g} / \mathrm{h}$ ), hepatic glucose-6-phosphate dehydrogenase activity (G6PDH) (preobese $0.68 \pm 0.07$; lean 0.71 $\pm 0.03 \mu \mathrm{mol} / \mathrm{g} / \mathrm{min}$ ) and serum insulin (preobese 64 \pm 2 ; lean $58 \pm 4 \mu \mathrm{U} / \mathrm{ml}$ ) were unchanged in 18 day preobese, suckling fafa rats. 3 days after weaning hepatic lipogenesis (preobese 25.3 \pm 2.0 ; lean $5.4 \pm$ $0.7 \mu \mathrm{mol} / \mathrm{g} / \mathrm{h}$ ) and G6PDH activity (preobese $4.5 \pm$ 0.5 ; lean $0.90 \pm 0.05 \mu \mathrm{mol} / \mathrm{g} / \mathrm{min}$ ) had increased in both lean and preobese rats although the values attained in preobese rats were significantly greater than in lean rats. When weaning was delayed there was no enhancement in lipogenesis, G6PDH or serum insulin in the preobese rat. The results suggest that the primary genetic defect in 'fatty' rats is not related to the increase in lipogenesis or serum insulin but may reflect a defective thermogenic process.
\end{abstract}

Key words: Preobesity, rectal temperature, hepatic lipogenesis, insulin, glucose-6-phosphate dehydrogenase, weaning, thermogenesis.

The characteristics of the fully developed genetically obese Zucker 'fatty' rat (fafa) have been described in detail $[1,2]$. The principle abnormalities are hyperphagia [3], hyperinsulinaemia $[4,5,6]$, and an excessive lipogenesis mainly of hepatic origin $[7,8,9,10]$. Although these changes are clearly related to the deposition of excess fat, it does not follow that any one of them represents the primary lesion. Indeed it has recently been shown that the excessive lipogenesis results mainly from the increase in food intake and serum insulin [10]. The major problem in identifying the primary genetic defect, which should be apparent before the obesity is visually detectable, has been the identification of the preobese fafa rat. Both a decrease in rectal temperature [11] and a low oxygen consumption $[12,13]$ have been used to identify the preobese 'ob/ob' mouse. Recently, it has been reported that the preobese fafa rat also has a low oxygen consumption [14]. We have extended this report to show that the preobese fafa rat may be identified by its lower rectal temperature and have investigated the rate of hepatic fatty acid synthesis in the preobese state.

\section{Materials and Methods}

Animals. The obese fafa rats were bred from lean heterozygote (Fafa) parents in the departmental animal facility. All animals were housed in a constant temperature room $\left(22^{\circ} \mathrm{C}\right)$ in a controlled light-dark cycle $(06.00-20.00 \mathrm{~h})$. Weaning was performed at day 20 unless otherwise stated.

Rectal Temperature. Suckling rats were separated from the mother and placed in an open cage for 15 minutes before measurement of temperature. All rectal temperatures were constant from 10 to 20 min after separation from mother. A thermistor (Light Labs., Brighton, England) was inserted a constant distance $(1.1 \mathrm{cms})$ into the rectum of all animals. After stabilization (5-7 secs) the temperature was recorded from a Temperature recorder $\left(15-45^{\circ} \mathrm{C}\right.$ range) (Light Labs., Brighton, England). All temperatures were measured between $10.00-11.30 \mathrm{~h}$ each day.

Hepatic Lipogenesis. $4 \mathrm{mCi}^{3} \mathrm{H}_{2} \mathrm{O}$ (Radiochemical Centre, Amersham, England) was injected IP into conscious animals. After one hour, the animals were killed by cervical dislocation and a cardiac blood sample rapidly obtained for measurement of the specific activity of serum water and serum insulin concentration. The liver 
Table 1. Rectal temperature, serum insulin, hepatic lipogenesis and hepatic glucose-6-phosphate dehydrogenase (G6PDH) in 6 week old lean and obese 'fatty' rats

\begin{tabular}{lllll}
\hline & Lean & Fatty & $\mathrm{p}$ \\
\hline $\begin{array}{l}\text { Rectal temperature } \\
\left({ }^{\circ} \mathrm{C}\right)\end{array}$ & $36.0 \pm 0.1$ & $34.8 \pm 0.1$ & $<0.001$ \\
$\begin{array}{l}\text { Serum insulin } \\
(\mu \mathrm{U} / \mathrm{ml})\end{array}$ & $58 \pm \pm$ & $149 \pm 17$ & $<0.001$ \\
$\begin{array}{l}\text { Hepatic fatty acid } \\
\text { synthesis } \\
(\mu \mathrm{mol} / \mathrm{g} \text { tissue/h) }\end{array}$ & $3.5 \pm 0.6$ & $34.5 \pm 2.0$ & $<0.001$ \\
$\begin{array}{c}\text { Hepatic G6PDH } \\
(\mu \mathrm{mol} / \mathrm{g} / \mathrm{min})\end{array}$ & $5.67 \pm 0.2$ & $15.9 \pm 1.17$ & $<0.001$ \\
\hline
\end{tabular}

Values represent Mean \pm SEM for 6 animals in each group

was removed and the lipids were extracted and fractionated as previously described [10]. Standard mouse chow (The Christopher Hill Group Ltd., Poole, Dorset) and water were freely available to all weaned animals throughout the experiment. Suckling animals were returned to their mother after ${ }^{3} \mathrm{H}_{2} \mathrm{O}$ injection. The rate of fatty acid synthesis is expressed as $\mu \mathrm{mol}$ fatty acid synthesised per wet weight of tissue. This was calculated as

dpm ${ }^{3} \mathrm{H}$ in fatty acid

spec. act ${ }^{3} \mathrm{H}_{2} \mathrm{O}(\mathrm{dpm} / \mu \mathrm{g}$ atom $\mathrm{H}) \times 13.3$

$[15,16]$.

Enzyme Activity. Hepatic glucose-6-phosphate dehydrogenase (E. C. 1.1.1.49) was assayed on the $10,000 \mathrm{~g}$ supernatant of a $10 \%$ (W/V) homogenate of liver in $50 \mathrm{mmol} / \mathrm{l}$ tris, $5 \mathrm{mmol} / 1 \mathrm{MgSO}_{4}, 1$ $\mathrm{mmol} / 1$ EDTA, $\mathrm{pH} 7.6$. The assay system contained $50 \mu \mathrm{mol}$ TRIS buffer, $\mathrm{pH} 7.6,0.2 \mu \mathrm{mol}$ NADP, $4 \mu \mathrm{mol} \mathrm{MgCl}_{2}$ in a final volume of $1.0 \mathrm{ml} ; 10 \mu \mathrm{l}$ of enzyme protein and $0.4 \mu \mathrm{mol}$ glucose-6-phosphate were added and the O.D. change at $340 \mathrm{~m} \mu$ followed on a Unicam SP 1800 spectrophotometer.

Serum Insulin. Triplicate $100 \mu \mathrm{l}$ samples were used in a radioimmunoassay procedure (Radiochemical Centre, Amersham, England) utilizing a rat insulin standard (Novo Laboratories, Denmark) as previously described. [10].

Statistical Analysis. Results are expressed as mean \pm SEM. The statistical significance of results was assessed by Student's ' $t$ ' test.

\section{Results}

The four variables measured in this study were rectal temperature, hepatic lipogenesis, hepatic glucose-6phosphate dehydrogenase (G6PDH) activity and serum insulin. The values in 6 week old lean and visually obese (fatty) rats are shown in Table 1 . The increase in hepatic lipogenesis in fatty rats was accompanied by an enhanced activity of liver G6PDH and raised serum insulin. However, rectal temperature of fatty rats was significantly depressed with a mean value more than $1^{\circ} \mathrm{C}$ lower than that in lean rats.

The rectal temperature of preobese fatty rats was measured daily from 16 days of age. Of 51 rats inves- tigated ( 5 litters from heterozygote parents) 16 animals showed consistently lower rectal temperatures, and all 16 animals became obese. The temperature profiles of 5 litters are presented in Table 2. Within each litter, there was a clear divergence into two groups on the basis of rectal temperature, although the temperatures were variable between different litters. In addition all male animals had a slightly lower rectal temperature (approximately $0.5^{\circ} \mathrm{C}$ ) than the females in the same litter, but the difference between lean and preobese rats was maintained. Measurement of rectal temperature before day 16 was difficult because of the thermistor probe size. However, in 1 litter (litter 1, Table 2) where this was achieved there was no detectable difference in the rectal temperatures of lean and preobese rats at day 14 .

Positive identification of preobese rats was made on the basis that the animals should show a low rectal temperature on three consecutive days (Days 16-18). This method of identification was adopted for the subsequent studies on hepatic lipogenesis, G6PDH and serum insulin in preobese fatty rats (Table 3).

At 18 days of age (litter A) the depressed rectal temperatures in the preobese fatty rats were again clearly shown. However at this age fatty acid synthesis, G6PDH activity and serum insulin levels were normal in the preobese fatty rats. In contrast, 3 days after weaning at 23 days of age (litter B) it is clear that while the preobese rats still showed a reduced rectal temperature, increases in hepatic fatty acid synthesis, G6PDH activity and serum insulin were now clearly evident. The values of these variables in preobese fatty rats may be contrasted with a 23 day old litter born of homozygous dominant parents (FaFa) which contained only lean offspring (Litter C). In such a litter, the values for rectal temperature, hepatic fatty acid synthesis, G6PDH activity and serum insulin were very similar to those of lean rats in litter B and clearly differed from preobese fatty rats. When weaning was delayed (litter D) 23 day old suckling animals, previously identified as preobese by their low rectal temperature, did not show any increase in hepatic fatty acid synthesis, G6PDH activity or serum insulin.

\section{Discussion}

The fundamental error which is responsible for the genetic lesion in the fatty rat is not understood. An increase in body fat has been observed prior to the increase in serum insulin and food intake $[1,17]$, but the investigation of the preobese stage has been hampered by the lack of a simple diagnostic method for 
Table 2. Rectal temperatures of lean and obese (fafa) rats from day 16 to day 35

\begin{tabular}{|c|c|c|c|c|c|c|c|c|c|c|}
\hline \multirow[b]{2}{*}{$\begin{array}{l}\text { Litter } \\
\text { no. }\end{array}$} & \multirow[b]{2}{*}{ n Day } & \multicolumn{8}{|c|}{ Rectal temperature $\left({ }^{\circ} \mathrm{C}\right)$} & \multirow[b]{2}{*}{$\begin{array}{l}\text { Body } \\
\text { weight }\end{array}$} \\
\hline & & 16 & 17 & 18 & 19 & 21 & 24 & 28 & 35 & \\
\hline \multirow{2}{*}{$\begin{array}{l}1 \text { lean } \\
\text { fafa }\end{array}$} & 9 & $34.8 \pm 0.2$ & $34.8 \pm 0.2$ & $35.0 \pm 0.1$ & $35.1 \pm 0.2$ & $35.3 \pm 0.1$ & $35.4 \pm 0.1$ & $35.5 \pm 0.1$ & $35.5 \pm 0.2$ & $70 \pm 5$ \\
\hline & 4 & $34.2 \pm 0.1$ & $34.2 \pm 0.1$ & $34.1 \pm 0.1$ & $34.1 \pm 0.1$ & $34.5 \pm 0.1$ & $34.5 \pm 0.2$ & $34.5 \pm 0.2$ & $34.4 \pm 0.2$ & $90 \pm 5$ \\
\hline \multirow{2}{*}{$\begin{array}{l}2 \text { lean } \\
\text { fafa }\end{array}$} & 7 & $35.7 \pm 0.2$ & $35.7 \pm 0.2$ & $35.7 \pm 0.2$ & $35.8 \pm 0.2$ & $35.9 \pm 0.2$ & $36.0 \pm 0.1$ & $36.0 \pm 0.1$ & $36.0 \pm 0.1$ & $72 \pm 4$ \\
\hline & 2 & $34.6 \pm 0.1$ & $34.6 \pm 0.1$ & $34.7 \pm 0.1$ & $34.8 \pm 0.1$ & $34.8 \pm 0.1$ & $34.8 \pm 0.1$ & $34.9 \pm 0.2$ & $34.8 \pm 0.2$ & $94 \pm 3$ \\
\hline \multirow{2}{*}{ 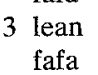 } & 6 & $35.5 \pm 0.3$ & $35.6 \pm 0.2$ & $35.9 \pm 0.2$ & $36.0 \pm 0.2$ & $36.1 \pm 0.2$ & $36.2 \pm 0.2$ & $36.3 \pm 0.2$ & $36.4 \pm 0.2$ & $68 \pm 4$ \\
\hline & 4 & $34.8 \pm 0.2$ & $34.8 \pm 0.1$ & $34.9 \pm 0.1$ & $34.9 \pm 0.2$ & $35.0 \pm 0.2$ & $34.8 \pm 0.3$ & $35.0 \pm 0.1$ & $35.0 \pm 0.1$ & $88 \pm 2$ \\
\hline \multirow{2}{*}{ 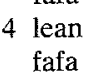 } & 7 & - & - & $36.1 \pm 0.2$ & $36.2 \pm 0.1$ & $36.2 \pm 0.2$ & $36.2 \pm 0.2$ & $36.2 \pm 0.2$ & $36.2 \pm 0.2$ & $74 \pm 4$ \\
\hline & 3 & - & - & $34.9 \pm 0.2$ & $34.7 \pm 0.1$ & $34.8 \pm 0.1$ & $34.8 \pm 0.1$ & $34.9 \pm 0.1$ & $34.9 \pm 0.1$ & $98 \pm 3$ \\
\hline \multirow{2}{*}{$\begin{array}{l}5 \text { lean } \\
\text { fafa }\end{array}$} & 6 & $35.7 \pm 0.2$ & $35.7 \pm 0.2$ & $35.7 \pm 0.2$ & $35.8 \pm 0.3$ & $35.9 \pm 0.2$ & $35.9 \pm 0.2$ & $36.0 \pm 0.1$ & $36.0 \pm 0.1$ & $70 \pm 4$ \\
\hline & 3 & $34.6 \pm 0.1$ & $34.6 \pm 0.1$ & $34.6 \pm 0.1$ & $34.6 \pm 0.1$ & $34.8 \pm 0.1$ & $34.9 \pm 0.2$ & $34.9 \pm 0.1$ & $34.9 \pm 0.1$ & $92 \pm 5$ \\
\hline
\end{tabular}

Rectal temperatures were measured between $10.00-11.30 \mathrm{~h}$. All animals were weaned on day 20 . Body weight is the weight at day 35

Table 3. The effect of age and suckling on hepatic lipogenesis and glucose-6-phosphate dehydrogenase activity in lean and preobese (fafa) rats

\begin{tabular}{|c|c|c|c|c|c|c|c|c|c|c|}
\hline \multirow[t]{2}{*}{ Age(d) } & \multirow[t]{2}{*}{ Diet } & & \multicolumn{4}{|c|}{ Rectal temperature $\left({ }^{\circ} \mathrm{C}\right)$} & \multirow{2}{*}{$\begin{array}{l}\text { Hepatic F.A. } \\
\text { synthesis } \\
(\text { umol/g/h) }\end{array}$} & \multirow{2}{*}{$\begin{array}{l}\text { G6PDH } \\
\text { (umol } / \mathrm{g} / \mathrm{min})\end{array}$} & \multirow{2}{*}{$\begin{array}{l}\text { Serum } \\
\text { insulin } \\
(\mu \mathrm{U} / \mathrm{ml})\end{array}$} & \multirow{2}{*}{ n } \\
\hline & & & Day 16 & 17 & 18 & 23 & & & & \\
\hline \multirow[t]{2}{*}{ A 18} & \multirow[t]{2}{*}{ Suckling } & fafa & $34.0 \pm 0.1$ & $34.1 \pm 0.1$ & $34.1 \pm 0.1$ & - & $0.6 \pm 0.1$ & $0.68 \pm 0.07$ & $64 \pm 2$ & 11 \\
\hline & & $\mathrm{Fa} ?$ & $36.0 \pm 0.1$ & $36.0 \pm 0.1$ & $36.0 \pm 0.1$ & - & $0.6 \pm 0.1$ & $0.71 \pm 0.03$ & $58 \pm 4$ & 45 \\
\hline \multirow[t]{2}{*}{ B 23} & \multirow{2}{*}{$\begin{array}{l}\text { Weaned } \\
\text { onto } \\
\text { Chow }\end{array}$} & fafa & $35.0 \pm 0.0$ & $34.9 \pm 0.2$ & $35.0 \pm 0.2$ & $35.2 \pm 0.2$ & $25.2 \pm 2.0^{\mathrm{a}}$ & $4.50 \pm 0.50^{\mathrm{a}}$ & $185 \pm 13^{a}$ & 10 \\
\hline & & $\mathrm{Fa}$ ? & $36.5 \pm 0.1$ & $36.5 \pm 0.1$ & $36.5 \pm 0.1$ & $36.6 \pm 0.2$ & $5.4 \pm 0.7$ & $0.90 \pm 0.05$ & $54 \pm 3$ & 28 \\
\hline C 23 & $\begin{array}{l}\text { Weaned } \\
\text { onto } \\
\text { Chow }\end{array}$ & $\mathrm{FaFa}$ & - & - & - & $36.8 \pm 0.5$ & $2.9 \pm 0.3$ & $0.87 \pm 0.04$ & $57 \pm 4$ & 8 \\
\hline \multirow[t]{2}{*}{ D 23} & \multirow[t]{2}{*}{ Suckling } & fafa & $35.1 \pm 0.1$ & $35.2 \pm 0.1$ & $35.0 \pm 0.1$ & $35.3 \pm 0.3$ & $2.3 \pm 0.3$ & $0.53 \pm 0.03$ & $59 \pm 5$ & 8 \\
\hline & & $\mathrm{Fa} ?$ & $36.5 \pm 0.1$ & $36.5 \pm 0.1$ & $36.5 \pm 0.1$ & $36.7 \pm 0.2$ & $1.8 \pm 0.2$ & $0.45 \pm 0.02$ & $54 \pm 3$ & 25 \\
\hline
\end{tabular}

All values are Mean \pm SEM a $\quad \mathrm{p}<0.001$ compared to lean mice in same group

differentiating between the lean and preobese fatty rats. We have demonstrated a simple method, the measurement of rectal hypothermia, which may be used to identify fatty rats prior to overt obesity. Every animal which became obese had a low rectal temperature at days 16-18; all lean animals had a higher rectal temperature. There were no exceptions to these observations. These findings are in agreement with those of Kaplan (1977) who showed a reduction of oxygen consumption in the preobese fatty rat [14]. They are also similar to reported findings in the preobese obob mouse [13].

The hypothermia can be demonstrated between 16-18 days of age and clearly precedes the especially high rates of hepatic lipogenesis, the accompanying induction of glucose-6-phosphate dehydrogenase and the increased plasma insulin in the fatty rats. Indeed the last three responses in the fatty rats can be prevented by postponing weaning and allowing the animal to remain on a suckling diet. Despite this, hypothermia is maintained. Thus although obesity in the fatty rat obviously requires enhanced lipogenesis and fat deposition to show the overt symptoms, it is clear that the hypothermia is related to a more fundamental lesion. It has been shown that the enhanced lipogenesis in young fafa rats may be virtually reduced to normal if the hyperphagia and hyperinsulinaemia are prevented shortly after weaning [10]. These results suggest that the excess fat deposits that have been shown at weaning in fafa rats by analysis of body composition must result from an increase in the deposition of dietary milk fat rather than from an increase in fatty acid synthesis.

Hypothermia could result from an increase in body heat loss or a decrease in heat generation. The latter seems most probable. This would suggest an area of metabolism which could be responsible for the genetic fault, namely the heat generating reactions within the body. Indeed, the impaired thermogenesis of the obese 'ob/ob' mouse has been attri- 
buted to a defective $\left(\mathrm{Na}^{+}+\mathrm{K}^{+}\right)$ATPase system [18]. The enzyme system is however normal in the fatty rat (York and Bray, unpublished observations). A number of possible abnormalities may be suggested. These include a decreased response of basal metabolic rate to thyroxine, decreased protein turnover, an increased $\mathrm{P}: \mathrm{O}$ ratio in mitochondrial oxidative phosphorylation and decreased rates of thermogenic substrate cycles. It can be readily appreciated that if the fatty rat produces less heat from a fixed amount of respiratory fuel (i. e. carbohydrate or fatty acid) then if energy expenditure (ATP consumption) for mechanical work is identical more energy can be stored as triglyceride or glycogen compared to the lean rat. It is unlikely that the hypothermia results from an impairment in the lipolytic capacity of white adipose tissue since total lipolysis in situ is increased at all ages in the fatty rat [19]. Furthermore, since the hpyothermia is evident even in old 'fafa' rats [20] when the role of brown fat in thermogenesis is diminished it is unlikely that the hypothermia results from defective brown fat metabolism. However it is possible that the impairment in thermogenesis of the fatty rat is a reflection of a hypothalamic defect. The possibility that a hypothalamic dysfunction is the basis of the obesity in fatty rats has been previously discussed [1].

\section{References}

1. Bray, G. A., York, D. A.: Genetically transmitted obesity in rodents. Physiol. Rev. 51, 598-646 (1971)

2. Herberg, L., Coleman, D.: Laboratory animals exhibiting obesity and diabetes syndromes. Metabolism 26, 59-99 (1977)

3. Bray, G. A., York, D. A.: Studies on food intake of genetically obese rats. Am. J. Physiol. 223, 176-179 (1972)

4. Lemmonier, D.: Hyperinsulinism in genetically obese rats. Horm. Metab. Res. 3, 287-288 (1971)

5. York, D. A., Steinke, J., Bray, G. A.: Hyperinsulinaemia and insulin resistance in genetically obese rats. Metabolism 21, 277-284 (1972)

6. Laburthe, M., Rancon, F., Freychet, P., Rosselin, G.: Glucagon and insulin from lean rats and genetically obese fatty rats.
Studies by radioimmunoassay, radioreceptor assay and bioassay. Diabetologia 11, 517-526 (1975)

7. Schonfeld, Y., Pfleger, B.: Overproduction of very low density lipoproteins in liver of genetically obese rats. Am. J. Physiol. 226, 1178-1184 (1971)

8. Martin, R. J.: In vivo lipogenesis and enzyme levels in adipose and liver tissues from pair-fed genetically obese and lean rats. Life Sci. 14, 1447-1453 (1974)

9. Bloxham, D.P., Fitzsimmons, S., York, D. A.: Lipogenesis in hepatocytes of genetically obese rats. Horm. Metab. Res. 9, 304-309 (1977)

10. Godbole, V., York, D. A.: Lipogenesis in situ in the genetically obese Zucker fatty rat (fafa): Role of hyperphagia and hyperinsulinaemia. Diabetologia 14, 191-197 (1978) (No.3)

11. Trayhurn, P., Thurlbey, P., James, W.P.T.: Thermogenic defect in preobese ob/ob mice. Nature 266, 60-62 (1977)

12. Kaplan, M., Leveille, G. A.: Prediction of preobesity among progeny from crosses of ob/ + mice. Proc. Soc. Exp. Biol. Med. 143, 925-928 (1973)

13. Kaplan, M.L., Leveille, G.A.: Core temperature, $\mathrm{O}_{2}$ consumption and early detection of ob/ob genotype in mice. Am. J. Physiol. 227, 912-915 (1974)

14. Kaplan, M. L.: Identification of the fa/fa genotype during the preobese phase of development. Fed. Proc. 36, 1149 (1977)

15. Windmeuller, H., Spaeth, A. E.: Perfusion in situ with tritium oxide to measure hepatic lipogenesis and lipid secretion. J. Biol. Chem. 241, 2891-2899 (1966)

16. Windmeuller, H., Spaeth, A.E.: De novo synthesis of fatty acid in perfused rat liver as determinant of plasma lipoprotein production. Arch. Biochem. Biophys. 122, 362-369 (1967)

17. Zucker, L. M., Antoniades, H. N.: Insulin and obesity in the Zucker genetically obese rat 'fatty'. Endocrinology 90, 1320-1330 (1972)

18. York, D. A., Bray, G. A., Yukimura, Y.: An enzymatic defect in the obese (ob/ob) mouse. Loss of the thyroid induced sodium-potassium dependent adenosine triphosphatase. Proc. Natl. Acad. Sci. USA 75, 477-481 (1978)

19. Zucker, L.M.: Fat mobilisation in vitro and in vivo in the genetically obese rat 'fatty'. I. Lipid. Res. 13, 234-243 (1972)

20. York, D. A., Hershman, J. M., Utiger, R. D., Bray, G. A.: Thyrotropin secretion in genetically obese tats. Endocrinology 90 , $67-72(1972)$

Received: November 8, 1977,

and in revised form: February 3, 1978

Dr. D. A. York

Department of Nutrition

School of Biochemical and Physiological Sciences

University of Southampton

Southampton S09 3TU

England 